\title{
92-kD Gelatinase Is Produced by Eosinophils at the Site of Blister Formation in Bullous Pemphigoid and Cleaves the Extracellular Domain of Recombinant 180-kD Bullous Pemphigoid Autoantigen
}

\author{
Mona Ståhle-Bäckdahl, " Mitsuse Inoue, " George J. Giudice," and William C. Parks` \\ *Department of Dermatology, Karolinska Hospital, 10401 Stockholm, Sweden; ${ }^{\ddagger}$ Department of Dermatology, Medical College of \\ Wisconsin, Milwaukee, Wisconsin 53226; and Division of Dermatology, Jewish Hospital at Washington University \\ Medical Center, St. Louis, Missouri 63110
}

\begin{abstract}
Eosinophils are prominent in bullous pemphigoid (BP), and proteases secreted from these and other inflammatory cells may induce disruption of the basement membrane. We used in situ hybridization and immunohistochemistry to localize the sites of 92-kD gelatinase expression in BP lesions. In all samples $(20 / 20)$, a strong signal for gelatinase mRNA was detected only in eosinophils and was most pronounced where these cells accumulated at the floor of forming blisters. No other cells were positive for enzyme mRNA. Both eosinophils and neutrophils, however, contained immunoreactive 92-kDgelatinase indicating that active expression occurred only in eosinophils. Degranulated eosinophils were also seen near blisters, and as demonstrated by gelatin zymography, immunoblotting, and ELISA, 92-kD gelatinase protein was prominent in BP blister fluid. No other gelatinolytic activity was specifically detected in BP fluid, and only small amounts of 92-kD gelatinase were present in suction blister fluids. As demonstrated in vitro, 92-kD gelatinase cleaved the extracellular, collagenous domain of recombinant 180-kD BP autoantigen (BP180, BPAG2, HD4, type XVII collagen), a transmembrane molecule of the epidermal hemidesmosome. Our results suggest that production and release $92-\mathrm{kD}$ gelatinase by eosinophils contributes significantly to tissue damage in BP. (J. Clin. Invest. 1994. 93:2022-2030.) Key words: bullous pemphigoid - 92-kD gelatinase $\bullet$ eosinophils $\bullet$ metalloproteinase $\bullet$ type XVII collagen
\end{abstract}

\section{Introduction}

Bullous pemphigoid (BP) ${ }^{1}$ is a relatively common blistering disease affecting primarily the elderly. Although the precise etiology of this condition is not known, the pathogenic mechanism is considered to be an autoimmune-mediated process

Address all correspondence to Mona Ståhle-Bäckdahl, M.D., Ph.D., Department of Dermatology, Karolinska Hospital, 10401 Stockholm, Sweden.

Received for publication 16 September 1993 and in revised form 13 December 1993.

1. Abbreviations used in this paper: APMA, $p$-aminophenylmercuric acetate; $\mathrm{BP}$, bullous pemphigoid; DAB, diaminobenzidine; GST, glutathione $S$-transferase.

J. Clin. Invest.

(C) The American Society for Clinical Investigation, Inc.

0021-9738/94/05/2022/09 \$2.00

Volume 93, May 1994, 2022-2030 leading to inflammation and subsequent blister formation (1). Histologic and ultrastructural studies have shown that the epidermis detaches from the underlying dermis within the lamina lucida of the basement membrane $(2,3)$. Along with epidermal-dermal separation is a loss of various structural and cellular components, such as anchoring filaments and hemidesmosomes, and eventually fragmentation of the basement membrane. The extensive destruction of extracellular matrix and cell adhesive proteins suggests that proteases released by migratory cells play a key role in blister formation.

A predominant influx of eosinophils into the skin is a characteristic and early event in BP $(2,3)$, but other leukocytes, notably neutrophils, are found in the associated infiltrate, albeit in lower concentrations. Granulocytes are thought to release proteases that damage the basement membrane, and indeed, degranulated eosinophils are seen in close association with the basal epidermis in the early stages of blister formation in BP $(2,3)$. Furthermore, cytochemical studies suggest that eosinophils release their intracellular contents in the lamina lucida at sites of blister formation (4). Proteolytic activity is found in BP blister fluid (5-8), but the precise nature and origin of this activity and which enzyme or enzymes contribute to blister formation is not known. Although interstitial collagenase is present in BP blister fluid, the levels are much lower compared to other types of blisters and are not much different from the levels in suction blisters (6). Similarly, the level of serine protease activity in BP blisters is lower than that detected in pemphigus lesions (8).

Metalloproteinase activity has been detected in BP blister fluid (5), and because these enzymes have a broad substrate specificity for extracellular matrix proteins $(9,10)$, and because they are expressed by migratory cells in response to inflammation (11), members of this family of proteases are likely to be involved in BP blister formation. We have reported that dermal eosinophils express $92-\mathrm{kD}$ gelatinase (also known as MMP-9) mRNA and protein (12,13). This metallogelatinase degrades denatured collagen, or gelatin, as well as elastin and native type $\mathrm{V}$ collagen $(14,15)$. In addition to interstitial proteins, $92-\mathrm{kD}$ gelatinase acts on various components of the basement membrane, such as type IV collagen, proteoglycans, entactin, and possibly laminin $(10,16)$.

Our in vivo findings, reported here, show that $92-\mathrm{kD}$ gelatinase is produced by eosinophils and is an abundant component of BP blister fluid. Since the complete proteolytic profile of this enzyme is not known and because it is a prominent product of eosinophils, $92-\mathrm{kD}$ gelatinase may cause the disruption leading to blister formation in BP by degrading important structural elements of skin. Interestingly, the two known BP autoantigens are components of epidermal hemidesmosomes, 
which attach the epidermis to the underlying stroma. The larger autoantigen, BP230 or BPAG1, is a $230-\mathrm{kD}$ intracellular protein $(17,18)$ with high homology to desmoplakin $I(19,20)$ and plectin (21). Because of its intracellular location, BP230 is probably not degraded by extracellular proteases. The other autoantigen, BP180 (also called BPAG2, HD4, and type XVII collagen ), is a $180-\mathrm{kD}$ transmembrane hemidesmosome protein with a large collagenous extracellular domain that has recently been shown to extent into the basement membrane (2226). Thus, degradation of the extracellular domain of BP180 may lead to dermal:epidermal separation, and, in fact, we demonstrate here that $92-\mathrm{kD}$ gelatinase degrades the collagenous domain of a recombinant form this autoantigen. Our findings suggest that the release of $92-\mathrm{kD}$ gelatinase by eosinophils is a critical event in blister formation and tissue damage seen in BP.

\section{Methods}

Tissues. Formalin-fixed, paraffin-embedded specimens of lesions from 20 patients with untreated BP were obtained from the Department of Dermatology, Karolinska Hospital (Stockholm, Sweden). Diagnosis of BP was confirmed by typical clinical and histopathologic features and by indirect immunofluorescence indicating that all patients had circulating autoantibodies against the basement membrane zone. Blood and fresh blister fluid were obtained within $24 \mathrm{~h}$ of blister formation sampled from seven inpatients with untreated BP. Suction blisters were induced on the ventral surface of the forearm of two healthy volunteers using a Dermovac device after continuous negative suction for $3-4 \mathrm{~h}$ at $200 \mathrm{mmHg}(27)$. Fluid was collected at 1 and $24 \mathrm{~h}$ after cessation of suction. Two additional BP blister samples (Nos. 8 and 9, Fig. 4) and fluid from three patients with blisters secondary to wart treatment by either bleomycin (No. 1) or cryotherapy (Nos. 2 and 3) were provided by Dr. Luis Diaz at the Medical College of Wisconsin (Milwaukee, WI). These fluids were sampled $\sim 24 \mathrm{~h}$ after blister formation. After centrifugation to remove cells, total protein concentration was measured by the Lowry method using bovine serum albumin as a standard, and blister fluid and serum samples were used directly for immunoblotting, zymography, and ELISA.

In situ hybridization. In situ hybridization was performed as described (28) with some modifications. All sections $(5 \mu \mathrm{m})$ were treated with proteinase K (Sigma Chemical Co., St. Louis, MO) and were washed in $0.1 \mathrm{M}$ triethanolamine buffer containing $0.25 \%$ acetic anhydride. Since eosinophils have been reported to non-specifically bind sulfated probes $(29,30)$, we minimized this potential artifact by pretreating specimens with $0.1 \mathrm{M}$ iodoacetamide in $0.1 \mathrm{M}$ triethanolamine, $\mathrm{pH} 8.2$, for $30 \mathrm{~min}$ before hybridization. Sections were covered with $25-50 \mu$ l of hybridization buffer containing $2.5-4 \times 10^{4} \mathrm{cpm} / \mu \mathrm{l}$ of ${ }^{35} \mathrm{~S}$-labeled antisense or sense RNA probe or $10^{5} \mathrm{cpm} / \mu \mathrm{l}$ of each ${ }^{35} \mathrm{~S}$-labeled 92-kD gelatinase-specific oligomers (see below). Specimens were incubated at $55^{\circ} \mathrm{C}$ (RNA probes) or $50^{\circ} \mathrm{C}$ (oligomers) for $18 \mathrm{~h}$ in a humidified chamber. After hybridization, slides were washed under stringent conditions, including treatment with RNase-A, except for sections hybridized with oligomeric probes, and were processed for autoradiography. After a 5-10-d exposure, the photographic emulsion was developed, and the slides were stained with Giemsa.

Probes for in situ hybridization. A 560-bp BamHI-Xbal fragment of $3^{\prime}$ end of the human 92-kD gelatinase cDNA subcloned in a Bluescript KS transcription vector (Stratagene, La Jolla, CA ) was linearized to allow transcription of antisense or sense RNA. This part of the cDNA encodes for the carboxyl terminus of the 92-kD gelatinase which displays considerable sequence divergence from similar domains of other metalloproteinases (31). Specimens were also hybridized with two ${ }^{35} \mathrm{~S}$-labeled oligomers complementary to $92-\mathrm{kD}$ gelatinase mRNA that were designed and prepared as described in detail (12). These oligomers are 23 and 25 nucleotides and are complementary to unique sequences within the region encoding the carboxy terminus of the 92$\mathrm{kD}$ enzyme. A 15 nucleotide $\mathrm{M}-13$ oligomeric universal primer was used as a negative control. We also hybridized sections for stromelysin1 mRNA using a full-length human cDNA provided by Dr. Markku Kurkinen, Wayne State University. We subcloned a 217-bp EcoRIXhol fragment coding of a unique portion of the 3 ' untranslated region of stromelysin-1 into a Bluescript $\mathrm{KSII}^{+}$plasmid to prevent crosshybridization to stromelysin-2 (32). Human collagenase (33) and matrilysin probes (34) were provided by Dr. Gregory I. Goldberg, Washington University (St. Louis, MO), and by Dr. Lynn Matrisian, Vanderbilt University (Nashville, TN). RNA probes were transcribed from linear cDNA templates and were labeled with $\alpha-\left[{ }^{35}\right.$ S $]$ UTP $(>1,200 \mathrm{Ci} /$ $\mathrm{mmol}$ ) under conditions recommended by and with reagents from Promega (Madison, WI) except that the transcription reaction was extended to $4 \mathrm{~h}$ to allow for the relatively inefficient incorporation of sulfated ribonucleotides. Calculated probe-specific activities were between $10^{8}$ and $10^{9} \mathrm{dpm} / \mu \mathrm{g}$. The specificity of the $92-\mathrm{kD}$ gelatinase (12), collagenase (35), stromelysin-1 (36), and matrilysin (34) probes for the appropriate sized mRNAs has been demonstrated by Northern blot analysis under similar conditions as for in situ hybridization.

Immunohistochemistry. Immunohistochemistry was done by the peroxidase-antiperoxidase technique (Vectastain ABC Kit; Vector Labs, Burlingame, CA) using diaminobenzidine (DAB) as a chromogenic substrate. Sections were pretreated with $0.1 \%$ trypsin in PBS for $30 \mathrm{~min}$ at $37^{\circ} \mathrm{C}$, and endogenous peroxidase activity was blocked by incubation $0.3 \% \mathrm{H}_{2} \mathrm{O}_{2}$ for $30 \mathrm{~min}$ at room temperature. Affinity purified anti-92-kD gelatinase antibody was diluted 1:2,000. The preparation and specificity of this antibody has been described (13). Controls included pre-immune serum and sections processed without primary antibody. Sections were counter stained with Harris hematoxylin. Eosinophils were identified by immunostaining with an antibody to eosinophilic cationic protein (EG2; Pharmacia AB, Uppsala, Sweden).

Combined immunohistochemistry and in situ hybridization was done as described (37). First, tissue macrophages were identified using a monoclonal antibody (KP-1; DAKO Corp., Carpinteria, CA) which reacts with CD-68, a specific macrophages marker (38). The CD-68 antibody was diluted $1: 300$ and incubated on sections at $37^{\circ} \mathrm{C}$ for $1 \mathrm{~h}$. Sections were processed without trypsin pretreatment, and all immunostaining solutions contained heparin to inhibit RNases (37). Next, the immunostained samples were hybridized for $92-\mathrm{kD}$ gelatinase mRNA with ${ }^{35}$ S-labeled RNA, processed for autoradiography, and stained with Harris hematoxylin.

Immunoblotting. Samples ( $25 \mu \mathrm{g}$ per lane of total protein) were resolved by electrophoresis through precasted $10 \%$ polyacrylamide gels (Novex, San Diego, CA). Proteins were transferred onto Immobilon-P PVDF Transfer Membrane (Millipore Intertech, Bedford, MA) with a semi-dry blotting system. Affinity-purified $92-\mathrm{kD}$ gelatinase antibody was diluted 1:500, and antigen was detected with a Vectastain $A B C$ kit using DAB as a chromogen.

Zymography. Zymography was done as described (39) using precasted, gelatin-embedded $10 \%$ polyacrylamide gels (Novex). Briefly, $50 \mu \mathrm{g}$ of total protein was separated by electrophoresis under nondenaturing conditions, incubated for $24 \mathrm{~h}$ at $37^{\circ} \mathrm{C}$ in $50 \mathrm{mM}$ Tris, $\mathrm{pH} \mathrm{8.0,5}$ $\mathrm{mM} \mathrm{CaCl}_{2}, 0.5 \mu \mathrm{M} \mathrm{ZnCl}$, and stained with Coomassie blue for $30 \mathrm{~min}$. Enzyme inhibition studies were done by adding $25 \mathrm{mM}$ EDTA or 1 mM phenylmethylsulfonylfluoride (PMSF; Sigma Chemical Co.) during the zymogram incubation. In some experiments, progelatinase was activated by pretreating samples with $1 \mathrm{mM} p$-aminophenylmercuric acetate (APMA; Sigma Chemical Co.) in $0.1 \mathrm{M}$ Tris, pH 8.0, for $1 \mathrm{~h}$ at $37^{\circ} \mathrm{C}$ before electrophoresis.

ELISA. For quantification of enzyme concentration, samples were lyophilized and reconstituted at 1:10 of their original volume, and competitive binding ELISA for $92-\mathrm{kD}$ gelatinase was performed using specific polyclonal antibody as described (40). This assay has nanogram sensitivity, is specific for $92-\mathrm{kD}$ gelatinase, and measures total enzyme whether free or bound to inhibitor or substrate or whether in an inac- 

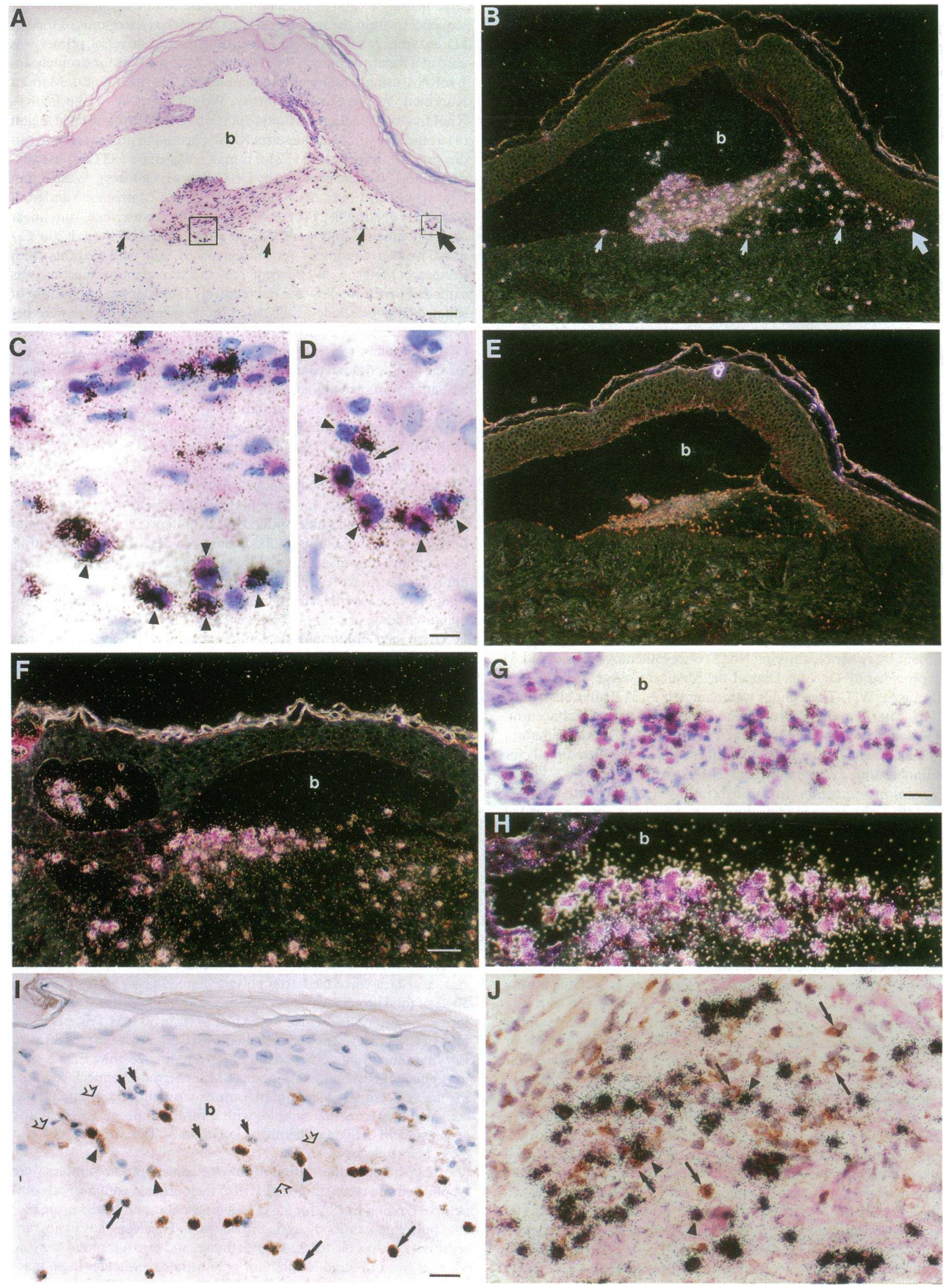
tive or active form. Other than dilution, samples were assayed without modification.

In vitro degradation assay. The $\mathrm{pGEX}-2 \mathrm{~T}$ prokaryotic expression system (Pharmacia LKB Biotechnology, Piscataway, NJ) was used to generate a 42-kD fusion protein consisting of glutathione $S$-transferase (GST) at its $\mathrm{NH}_{2}$ terminus and a portion of the BP180 ectodomain at its $\mathrm{COOH}$ terminus (26). The BP180 moiety of this fusion protein, GST-N $\Delta 1$, consists of 60 amino acids of the non-collagenous, NC16A, and 80 amino acids of the collagenous sequences from domains COL14 to COL15 (See Fig. $5 A$ ). Recombinant GST-N $\Delta 1$ and GST encoded by pGEX-2T were expressed in $E$. coli and were purified by affinity chromatography as described $(26,41)$.

Purified human $92-\mathrm{kD}$ progelatinase and activated human interstitial collagenase were provided by Dr. Howard Welgus, Washington University. Gelatin, used as a known substrate for $92-\mathrm{kD}$ gelatinase, was denatured at $60^{\circ} \mathrm{C}$ for $15 \mathrm{~min}$, then kept at $37^{\circ} \mathrm{C}$ until used. Purified progelatinase was activated with $1 \mathrm{mM}$ APMA, $5 \mathrm{mM} \mathrm{NaOH}$ at $37^{\circ} \mathrm{C}$ for $1 \mathrm{~h}$ as described (16). Recombinant proteins ( $10 \mu \mathrm{g}$ each) were incubated with or without $1.5 \mu \mathrm{g}$ activated metalloenzyme or with $0.8 \mu \mathrm{g}$ trypsin in $10 \mathrm{mM}$ Tris- $\mathrm{HCl}, \mathrm{pH} 7.5,1 \mathrm{mM} \mathrm{CaCl}_{2}$ in a total volume of $50 \mu \mathrm{l}$ for $18 \mathrm{~h}$ at $25^{\circ} \mathrm{C}(16)$. The final concentration of metalloenzyme was $3.2 \times 10^{-7} \mathrm{M}$ for $92-\mathrm{kD}$ gelatinase and $6.5 \times 10^{-7}$ $\mathrm{M}$ for collagenase. Gelatin digestion was done for $1 \mathrm{~h}$ at $37^{\circ} \mathrm{C}$ to prevent reformation of triple helices. Reactions were terminated with an equal volume of reducing sample buffer and were heated at $100^{\circ} \mathrm{C}$ for $10 \mathrm{~min}$. Reaction components (equivalent to $1 \mu \mathrm{g}$ of test protein) were resolved by electrophoresis through $12 \%$ SDS-polyacrylamide gels under denaturing conditions and stained with Coomassie blue or with silver nitrate.

\section{Results}

In situ hybridization. All archival tissue samples of BP had morphologically identifiable eosinophils which accumulated in the upper part of the dermis and at the dermal-epidermal junction. Immunostaining for eosinophilic cationic protein confirmed the presence of numerous eosinophils in all samples (data not shown). In 15/20 samples, the epidermis was fully separated from the underlying dermis (for example, see Fig. 1 $A$ ). The remaining five samples represented earlier lesions with inflammation in the upper dermis and incomplete (see Fig. 1, $F$ and $I$ ) or no blister formation.

As demonstrated by in situ hybridization, numerous cells were strongly positive for $92-\mathrm{kD}$ gelatinase mRNA, and typically these cells clustered at sites of blister formation and along the dermal ridge of blister (Fig. 1, $A, B$, and $F$ ). Under high magnification, signal for $92-\mathrm{kD}$ gelatinase mRNA was confined to eosinophils, as identified by Giemsa staining and by their characteristic bilobar nuclear morphology, and all eosinophils in all samples were positive for enzyme mRNA (Fig. 1, $C$, $D, G$, and $H)$. No autoradiographic signal was seen in any other cell type, notably neutrophils (Fig. $1 D$ ) and keratinocytes, both of which have been reported to secrete $92-\mathrm{kD}$ gelatinase in culture $(14,42)$. Since macrophages also have the capacity to synthesize and release $92-\mathrm{kD}$ gelatinase $(11,43)$, we combined immunohistochemistry for CD68, a macrophage-specific marker, with in situ hybridization to see if any of the cells positive for $92-\mathrm{kD}$ gelatinase mRNA were macrophages (Fig. $1 \mathrm{~J}$ ). No CD68-positive cells had autoradiographic signal for $92-\mathrm{kD}$ gelatinase mRNA indicating that, at least in BP, macrophages do not activity produce this metalloproteinase. In addition, no signal for collagenase, stromelysin1 , or matrilysin mRNAs was seen (data not shown) indicating that $92-\mathrm{kD}$ gelatinase is the principal metalloproteinase expressed in BP lesions.

No signal was seen on sections hybridized with sense RNA (Fig. $1 E$ ). Because there are reports of nonspecific autoradiographic signal in eosinophils $(29,30)$, we also hybridized sections with two ${ }^{35} \mathrm{~S}$-labeled oligomers which are complementary to unique sequences in 92-kD gelatinase mRNA (12). Hybridization with these probes gave results that were identical to those obtained with the antisense RNA probe, namely strong signal for 92-kD gelatinase mRNA was seen only in eosinophils (results not shown). Sections hybridized with an ${ }^{35}$ S-labeled M-13 primer, used as a nonspecific oligomeric sequence, had only background autoradiographic signal (results not shown).

Immunohistochemistry. We used an affinity purified antibody for human $92-\mathrm{kD}$ gelatinase protein in an immunohistochemical assay to verify that eosinophils in the BP samples synthesized enzyme protein. In agreement with the in situ hybridization findings, eosinophils were immunoreactive for $92-$ kD gelatinase protein (Fig. 1 I, arrowheads). Consistent with our previous data (13), neutrophils also showed positive immunostaining (Fig. 1, I, long arrows). The lack of detectable 92$\mathrm{kD}$ gelatinase mRNA in neutrophils indicates that a precursor cell produces the protein (13). No signal was seen in sections processed with preimmune serum or without primary antibody (data not shown). A number of morphologically identifiable

Figure 1. Expression of 92-kD gelatinase in bullous pemphigoid. ( $A$ and $B$ ) Paired bright-field and dark-field photomicrographs of a section of bullous pemphigoid hybridized with a ${ }^{35} \mathrm{~S}$-labeled antisense RNA for $92-\mathrm{kD}$ gelatinase mRNA and stained with Giemsa. A blister $(b)$ separates the overlying epidermis from the dermis. An acute inflammatory infiltrate is seen in the center of the specimen, which, as seen under dark-field illumination $(B)$, is filled with cells having an intense signal for $92-\mathrm{kD}$ gelatinase mRNA. Numerous positive cells are seen along the dermal ridge (small arrows) and are accumulated at the junction of intact and blistering epidermis (large arrow). Autoradiography was for $5 \mathrm{~d}$. Bar, $100 \mu \mathrm{m}$. ( $C$ and $D$ ) The areas in the large and small boxes in $A$ are presented under higher magnification in $C$ and $D$, respectively. Autoradiographic signal for $92-\mathrm{kD}$ gelatinase mRNA is seen only in eosinophils (arrowheads) along the dermal ridge, within the infiltrate, and at the blister edge. Other cells, such as neutrophils (arrow) and keratinocytes, had no signal for 92-kD gelatinase mRNA. Bar, $10 \mu \mathrm{m}$. ( $E$ ) No autoradiographic signal was detected in sections hybridized with an ${ }^{35}$ S-labeled sense RNA probe transcribed from $92-k D$ gelatinase cDNA. Autoradiography was for $10 \mathrm{~d}$. Magnification is the same as $A$. $(F)$ In another sample of bullous pemphigoid, many positive cells are seen on the dermal side of a blister $(b)$. Autoradiography was for $5 \mathrm{~d}$. Bar, $50 \mu \mathrm{m}$. ( $G$ and $H$ ) Under higher magnification, all cells with signal for $92-\mathrm{kD}$ gelatinase were differentially stained with Giemsa and had a morphology of eosinophils. Bar, $20 \mu \mathrm{m}$. (I) Immunostaining for 92-kD gelatinase showed immunoreactive eosinophils (arrowheads) and neutrophils (long arrows) in the dermis near to a blister $(b)$. Some eosinophils had weak to no immunoreactivity (small arrows) suggesting that the enzyme had been released. Indeed, punctate staining was evident in the extracellular space surrounding immunoreactive cells (open arrows). The section was counterstained with hematoxylin. Bar, $25 \mu \mathrm{m}$. ( $J$ ) A section of bullous pemphigoid was immunostained for CD68, a macrophage-specific cell surface marker, using DAB as a chromogen, which forms a brown precipitate, then were assayed for $92-\mathrm{kD}$ gelatinase mRNA by in situ hybridization. Macrophages (arrows) had no signal for 92-kD gelatinase mRNA (arrowheads). Magnification is the same as $I$. 
eosinophils had little or no staining for $92-\mathrm{kD}$ gelatinase protein (Fig. $1 I$, short arrows). When we have assayed samples of other diseases, such as squamous cell carcinoma (13) or various lung disorders (our unpublished findings), eosinophils consistently stained much more intensely for $92-\mathrm{kD}$ gelatinase protein than we saw in the BP samples, even though the specimens were fixed and processed by similar protocols. Thus, the relatively weak staining in the BP specimens suggests that eosinophils have degranulated and released the enzyme. Indeed, punctate staining was consistently seen in the extracellular space (Fig. 1 I, open arrows) around the weakly positive cells, which may indicate the presence of the secreted enzyme. No such extracellular staining was seen in sections processed with preimmune serum or without primary antibody (data not shown).

Gelatinase in blister fluid. To directly assess the presence of 92-kD gelatinase in BP blisters, fluid was collected from inpatients within $24 \mathrm{~h}$ of blister formation. Samples were gently centrifuged to remove any cells and were processed for gelatin zymography and immunoblotting. In all BP samples, a prominent gelatinolytic band was seen at $92 \mathrm{kD}$ (Fig. $2 A$ ), and immunoblotting with an affinity-purified antibody verified that this degradative activity was $92-\mathrm{kD}$ gelatinase (Fig. $2 B$ ). As a control, suction blisters were induced in healthy volunteers, and fluid was sampled at $1 \mathrm{~h}$ after blister formation and $24 \mathrm{~h}$ later, at which time the inflammatory response is maximal (44). Blisters induced by gentle suction and heat in healthy volunteers serve as an appropriate control since the mechanical separation occurs at the same level within the epidermal basement membrane as in BP (27). No gelatinolytic band near $92 \mathrm{kD}$ was seen in these samples nor was any immunoreactive material detected (Fig. 2). In all samples, gelatinolytic activity was also detected at $72 \mathrm{kD}$ (Fig. $2 A$ ), which most likely represents 72-kD gelatinase, a closely related yet distinct gene product (31). The minor gelatinolytic bands at about 110 and $200 \mathrm{kD}$ in BP samples 1 and 4 (Fig. $2 A$ ) are probably complexes that were not separated under the nondenaturing condition used for the zymogram (45).

The identity of the 92-kD gelatinolytic activity as a metalloproteinase was determined by inhibition and activation studies. All gelatinolytic activity was fully inhibited by $25 \mathrm{mM}$ EDTA (Fig. $3 A$ ), but PMSF, a serine protease inhibitor, did not affect degradation (Fig. $3 \mathrm{~B}$ ). These findings indicate further that the specific band in the BP samples was $92-\mathrm{kD}$ gelatinase. As is expected for a metalloproteinase, organomercurial activation converted the $92-\mathrm{kD}$ band to one at $\sim 84 \mathrm{kD}$ and the $72-\mathrm{kD}$ band to one at $\sim 63 \mathrm{kD}$ (Fig. $3 C$ ).

The amount of $92-\mathrm{kD}$ gelatinase in BP blister was quantified by ELISA. Although the levels of enzyme varied among BP samples, the levels were markedly higher than those detected in 1 - and 24-h suction blister fluid samples or in fluid from blisters resulting from wart treatment (Fig. 4). In fact, the values for the non-pemphigoid blister samples were not much above background levels of the ELISA. Consistent with $92-\mathrm{kD}$ gelatinase being produced and secreted locally, only background levels of enzyme were detected in serum samples from BP patients and from volunteers for suction blisters (data not shown).

92-kD gelatinase degrades $B P 180$. To assess if $92-\mathrm{kD}$ gelatinase contributes to blister formation, we incubated purified, activated enzyme with a $42-\mathrm{kD}$ recombinant fusion protein, GST-N $\Delta 1$, containing $\sim 16 \mathrm{kD}$ of the extracellular sequences of BP180, including a large portion of the first and largest col- lagenous domain (Fig. $5 \mathrm{~A}$ ). Although the tertiary structure of native $\mathrm{BP} 180$ is not known, reactions were done at $25^{\circ} \mathrm{C}$ to provide conditions permissive for potential formation of triple helices among recombinant monomers. Based on a decrease of $\sim 8 \mathrm{kD}, 92-\mathrm{kD}$ gelatinase cleaved recombinant BP180 at the beginning of the collagenous ectodomain, and as for gelatin, degraded the collagenous sequences into fragments too small to be seen on the gel (Fig. $5 \mathrm{~B}$ ). The GST portion of the fusion protein was not cut by $92-\mathrm{kD}$ gelatinase (Fig. $5 B$ ). The degradation of recombinant BP1 180 by $92-\mathrm{kD}$ gelatinase was specific since minor contaminating bacterial proteins were not digested by this enzyme (Fig. $5 B$ ) and because the protein was not degraded by purified human interstitial collagenase (data not shown). Predictably, trypsin cleaved BP180 as well as the contaminating bacterial proteins (Fig. $5 \mathrm{~B}$ ).

\section{Discussion}

A massive influx of eosinophils, especially at the dermal-epidermal junction, is a characteristic feature of BP. Although the ultimate cause of basement membrane injury is unknown, this granulocytic inflammation likely plays a key role in tissue destruction. Indeed, degranulated eosinophils accumulate along the epidermal side of the basement membrane, and this infiltration is temporally and spatially associated with blister for-
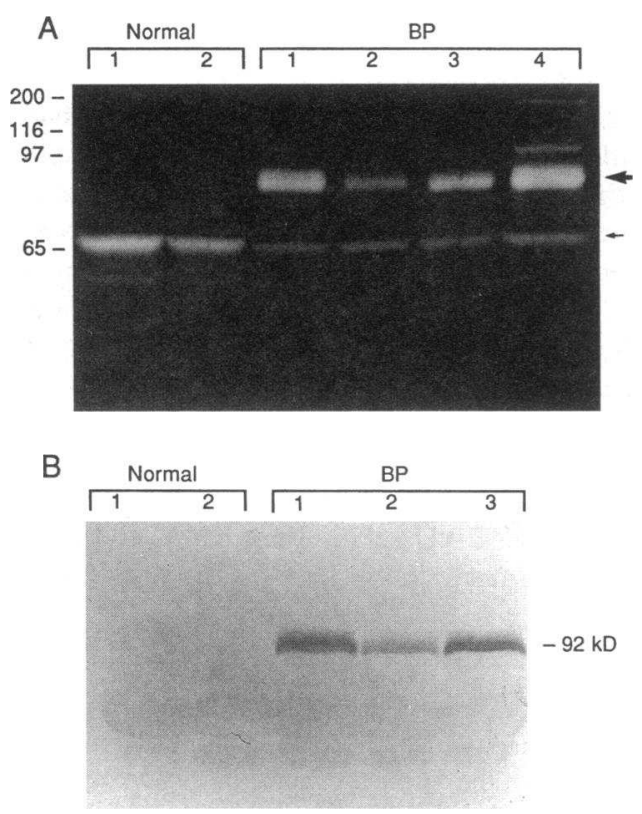

Figure 2. 92-kD gelatinase is present in bullous pemphigoid blister fluid. $(A)$ Samples of blister fluid from 24-h suction blisters (Normal) from two volunteers and from four patients with bullous pemphigoid $(B P)$ were analyzed by gelatin zymography as described in Methods. A prominent gelatinolytic band, which appears as a clear area on the Coomassie-stained gel, migrating at $\sim 92 \mathrm{kD}$ (large arrow) was seen only in the bullous pemphigoid samples. A smaller band, at $\sim 72$ $\mathrm{kD}$, was present in all samples (small arrow). The higher molecular weight bands seen in BP samples 1 and 4 probably represent complexes of $92-\mathrm{kD}$ gelatinase which are not separated in the non-denaturing gel. The white jagged line in the center is a crack in the gel. (B) Immunoblotting with an affinity-purified antibody to human 92$\mathrm{kD}$ gelatinase demonstrated the presence of this enzyme only in bullous pemphigoid blister fluid. 

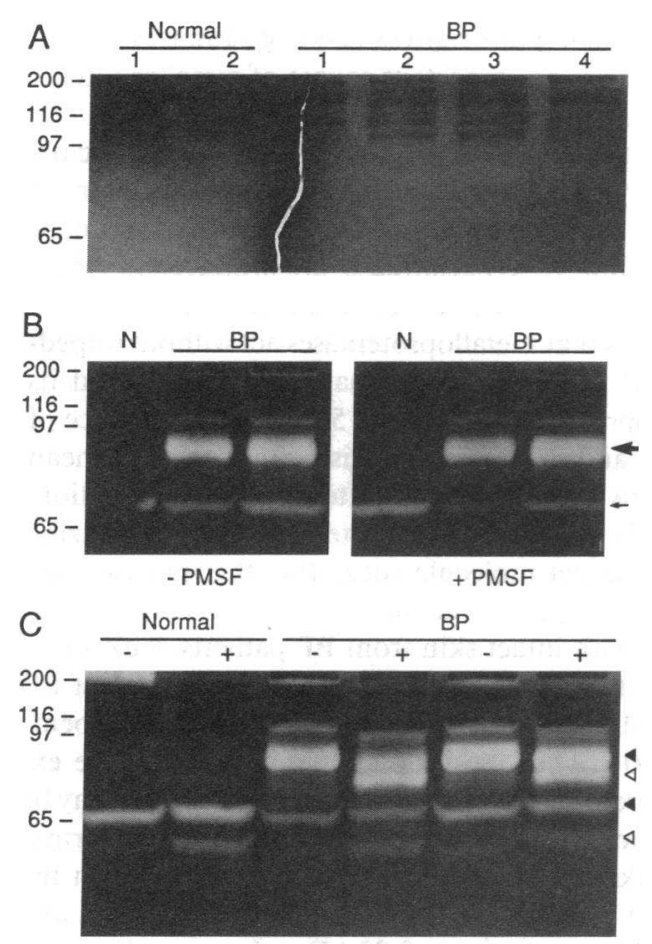

Figure 3. Characterization of gelatinolytic activity in bullous pemphigoid blister fluid as a metalloproteinase. $(A)$ Samples of blister fluid from 24-h suction blisters (Normal) from two volunteers and from four patients with bullous pemphigoid $(B P)$ were analyzed by gelatin zymography. Gels were incubated with $25 \mathrm{mM}$ EDTA which blocked all gelatinolytic activity. $(B)$ Incubating gels with $1 \mathrm{mM}$ PMSF did not block gelatinolytic activity at either 92 (large arrow) or $72 \mathrm{kD}$ (small arrow). Gelatinolytic activity at $92 \mathrm{kD}$ was not detected in samples of suction blister fluid $(N)$ but was prominent in samples from patients with bullous pemphigoid $(B P)$. (C) Samples were treated with $1 \mathrm{mM}$ APMA to activate metalloproteinases. The gelatinolytic bands at 92 and $72 \mathrm{kD}$ (solid arrowheads) shifted to lower molecular weight species (open arrowheads) in samples pretreated with APMA (+).

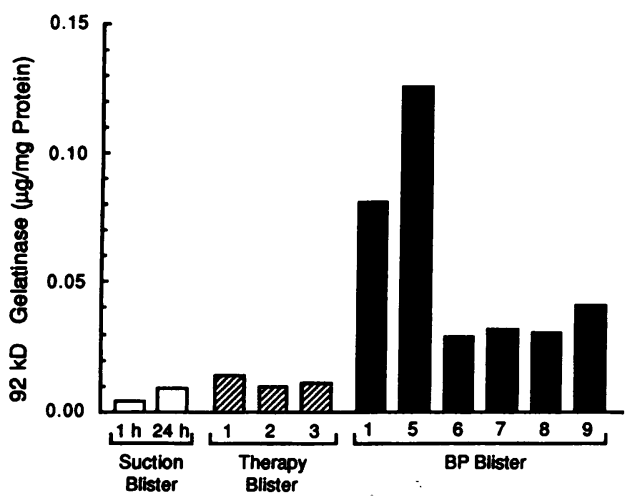

Figure 4. Quantification of 92-kD gelatinase in blister fluid. Fluid was sampled from a suction blister at 1 and $24 \mathrm{~h}$ after blister formation, from three patients with blisters secondary to wart treatment by bleomycin (1) or cryotherapy ( 2 and 3 ), and from six bullous pemphigoid (BP) patients ( 1 and 5-9). Samples were processed for ELISA as described. The data are the mean of triplicate determinations and are normalized to total protein.
A

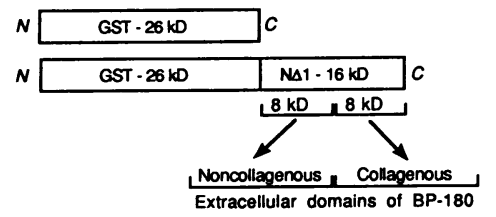

B

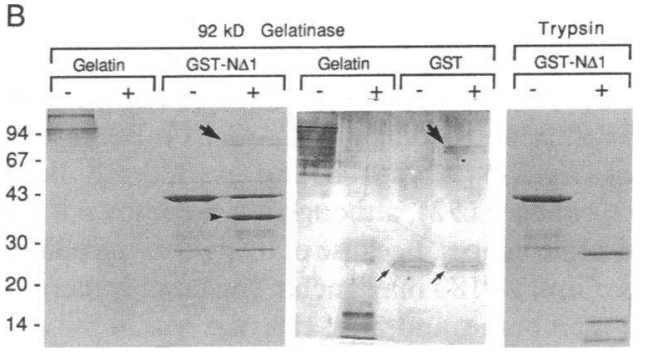

Figure 5. Degradation of recombinant BP180 by $92-\mathrm{kD}$ gelatinase. $(A)$ Illustration of the recombinant proteins used in these studies. $G S T$ is $26 \mathrm{kD}$. The fusion protein, GST-N $\Delta 1$, is $42 \mathrm{kD}$ and contains GST and equal portions of two contiguous extracellular domains of BP180 as described in Methods. $(B)$ Gelatin, the fusion protein GST-N $\Delta 1$, and GST were incubated with $(+)$ or without $(-)$ APMA-activiated 92-kD gelatinase, and the products were resolved by SDS-PAGE. Gelatin was completely degraded by $92-\mathrm{kD}$ gelatinase. About $8 \mathrm{kD}$ was cleaved from GST-N $\Delta 1$ resulting in a product of $\sim 34 \mathrm{kD}$ (arrowhead), but bacterial proteins, seen at about 45, 32 (triplet), and $28 \mathrm{kD}$, were not digested. As well, purified recombinant GST protein was not cut by $92-\mathrm{kD}$ gelatinase. The GST products were silver stained, and the 26-kD GST bands are marked by small arrows. The large arrows mark activated $92-\mathrm{kD}$ gelatinase, which migrates as a doublet (see Fig. $3 C$ ). Trypsin effectively cleaved recombinant and bacterial proteins.

mation and destruction of the basement membrane $(2,3)$. In pemphigus vulgaris, another autoimmune blister disease, autoantibody binding to the epidermis induces endogenous protease production leading to detachment and acantholysis (46, 47). In contrast, BP autoantibodies do not induce protease production by keratinocytes (46), and models of BP blister formation using isolated cells or intact skin demonstrate the requirement of activated migratory cells (48) or of BP blister fluid (49). Thus, the proteases that cause epidermal-dermal separation in BP are most likely products of leukocytes, and our findings suggest that matrix-degrading enzymes, principally $92-\mathrm{kD}$ gelatinase, produced and secreted by the abundant eosinophils, contribute to detachment of the epidermis in BP. Although $92-\mathrm{kD}$ gelatinase is prominently expressed in $\mathrm{BP}$, this metalloproteinase may contribute to tissue damage in various bullous diseases, as well as in other destructive lesions. We focused on BP because of the potential that large quantities of 92-kD gelatinase would be produced by eosinophils.

Blister formation in BP occurs primarily in the lamina lucida leaving the basal lamina at the floor of the blister. Still, in the fully developed blisters the lamina basalis is extensively damaged and eventually disappears $(1,2)$. Although 92-kD gelatinase degrades laminin and type IV collagen (10), immunohistologic findings with antibodies against basement membrane proteins indicate that blister formation in BP occurs adjacent to the basal surface of the epithelium and not within the basement membrane (50). Thus, if separation results from cleavage of an integral basement protein, immuno- 
staining for type IV collagen or laminin should be evident on the upper face of BP blisters, which it is not.

Blister formation may occur by selective degradation of newly or not yet discovered components. Recently, two distinct autoantigens, BP230 and BP180, so named for their molecular mass, were cloned and characterized. The larger of these, BP230, is an intracellular protein $(17,19)$, and thus, it seems unlikely that it would be a target for degradation by extracellular proteases. BP180, however, is a transmembrane hemidesmosome protein with a large extracellular portion comprised of 15 collagenous domains $(22,23,51)$. Because of its abundance of Gly-X-Y repeats, BP180 has recently been named type XVII collagen (52), although it is not known if the monomers form triple helices. Because of its rigid extracellular structure and location, BP180 may anchor the basal epidermis to the basement membrane, and thus, cleavage within the collagenous domain would be a likely site for dermal-epidermal separation. Our in vitro degradation results suggest that the first and largest collagenous domain of BP180 is efficiently degraded by $92-\mathrm{kD}$ gelatinase. Although blister formation is probably more complex, involving the degradation of other structural molecules along with the disruption of cell-matrix contacts, our findings indicate that degradation of the extracellular domain of BP180 may be a critical event in the pathogenesis of BP. Our conclusion is tempered somewhat by the use of a truncated, recombinant substrate. As stated, the tertiary structure of native BP180 is not known, and confirmational alterations of the primary protein product, which would not be duplicated in the bacterial expression system, may affect the protease specificity.

In our studies, we found no evidence of specific production or release of other metalloproteinases. Other than the storage of 92-kD gelatinase by neutrophils, metalloproteinases are actively secreted by the cells that make them. Thus, our negative results for expression of interstitial collagenase, stromelysin-1, and matrilysin mRNAs would indicate that these enzymes are not produced in the area of blister formation in BP. Considering their substrate specificity, it is reasonable that these enzymes are not involved in BP. Collagenase cleaves only interstitial fibrillar collagens (types I, II, III, and X), which are not found in basement membrane, and in our studies reported here, human collagenase did not degrade recombinant BP180. Furthermore, studies by Welgus et al. showed that relatively little collagenase is present in BP blister fluid (6), and other studies by us showed that collagenase mRNA is not expressed by any cell near the site of blister formation in BP (50). Stromelysin-1 degrades various extracellular matrix proteins including components of the dermal basement membrane such as proteoglycans, type IV collagen, and laminin $(10,53)$. Since these components remain with the attached basement membrane, they are probably not the sites of tissue destruction in BP. Although matrilysin has a broad substrate specificity, its production seems to be limited to circulating monocytes (54) and glandular epithelium $(34,55)$.

In all blister fluid samples, we found detectable levels of $72-\mathrm{kD}$ gelatinase. This enzyme is closely related to $92-\mathrm{kD}$ gelatinase but typically is made by different cell types $(11,31)$. Because both metallogelatinases share the same substrate specificity (10), the 72-kD enzyme may contribute to degradation of the same molecules that the 92-kD enzyme recognizes. Preliminary observations (M. Ståhle-Bäckdahl, unpublished find- ings) suggest that eosinophils express $72-\mathrm{kD}$ gelatinase indicating that these cells are an important source of metalloproteinases.

Metalloenzyme activity is regulated, in part, by specific inhibitors, and TIMP-1 is present in BP fluid (6). However, in other studies, we have usually found that TIMP-1 and metalloenzymes, including $92-\mathrm{kD}$ gelatinase, are produced in different locations $(12,33,50,56)$. This spatially distinct pattern of expression suggests that metalloproteinases act without impedance from TIMP-1. Since TIMP-1 has functions beyond its role as a metalloproteinase inhibitor $(57,58)$, the presence of 92-kD gelatinase and TIMP-1 in BP blister fluid does not mean that these proteins had interacted at sites of tissue destruction.

Cells probably secrete metalloproteases upon recognizing the extracellular target molecule suggesting that precise cellmatrix interactions regulate enzyme release $(50,59)$. Interestingly, in studies with intact skin from BP patients, leukocytes bind preferentially to the basement membrane at sites of BP lesions compared to that of unaffected normal-appearing pemphigoid skin (60). Thus, eosinophil chemotaxis and the expression and secretion of $92-\mathrm{kD}$ gelatinase by these cells may be influenced by some factor originating at the site of BP formation. It seems likely that local mechanisms originating at the site of BP blister formation direct eosinophil chemotaxis and the expression and secretion of $92-\mathrm{kD}$ gelatinase. Whether these events are mediated by immune complexes or by some as-of-yet unknown stimulus remains to be elucidated.

\section{Acknowledgements}

This work was supported by grants from the Karolinska Institute, the Lars Hierta Foundation, the Tore Nilsson Foundation, the Smedby Foundation, the Finsen Foundation, and the Edvard Welander Foundation and by grants HL48762, HL29594, and AR40410 from the National Institutes of Health.

We thank Dr. Howard G. Welgus and Catherine Fliszar for the 92-kD gelatinase antibody, enzymes, and for many helpful discussions, Dr. Luis Diaz for blister fluid samples, Dr. Gregory I. Goldberg for the 92-kD gelatinase and interstitial collagenase cDNAs, Dr. Lynn Matrisian for the matrilysin cDNA, Dr. Markku Kurkinen for the stromelysin-1 cDNA, and Kerstin Bruce, Margaret Kolodziej, Jill Roby, Teresa Tolley, and Leslie Cottle for excellent technical assistance.

\section{References}

1. Anhalt, G. F., and L. Morrison. 1993. Pemphigoid: bullous, gestational, and cicatricial. In Bullous Diseases. T. T. Provost and W. L. Weston, editors. Mosby Year Book, St. Louis, MO. 63-114.

2. Schaumburg-Lever, G., C. E. Orfanos, and W. F. Lever. 1971. Electron microscopic study of bullous pemphigoid. Arch. Dermatol. 106:662-667.

3. Dvorak, A. M., M. C. Mihm, J. E. Osage, T. H. Kwan, K. F. Austen, and B. U. Wintroub. 1982. Bullous pemphigoid, an ultrastructural study of the inflammatory response: eosinophil, basophil and mast cell granule changes in multiple biopsies of one patient. J. Invest. Dermatol. 78:91-101.

4. Dubertret, L., B. Bertaux, M. Fosse, and R. Touraine. 1980. Cellular events leading to blister formation in bullous pemphigoid. Br. J. Dermatol. 104:615623

5. Oikarinen, A. I., J. J. Zone, A. R. Ahmed, U. Kiistala, and J. Uitto. 1983. Demonstration of collagenase and elastase activities in blister fluids from bullous skin diseases. Comparison between dermatitis herpetiformis and bullous pemphigoid. J. Invest. Dermatol. 81:261-266.

6. Welgus, H. G., E. A. Bauer, and G. P. Stricklin. 1986. Elevated levels of human collagenase inhibitor in blister fluids of diverse etiology. J. Invest. Dermatol. 87:592-596. 
7. Grando, S. A., B. T. Glukhenky, G. N. Drannik, A. P. Kostromin, and A. I Chernyavsky. 1989. Cytotoxic proteases in blister fluid of pemphigus and pemphigoid patients. Int. J. Tiss. React. 11:195-201.

8. Grando, S. A., B. T. Glukhenky, G. N. Drannik, E. V. Epshtein, A. P Kostromin, and T. A. Korostash. 1989. Mediators of inflammation in blister fluids from patients with pemphigus vulgaris and bullous pemphigoid. Arch. Dermatol. 125:925-930.

9. Matrisian, L. M. 1990. Metalloproteinases and their inhibitors in matrix remodeling. Trends Genet. 6:121-125.

10. Alexander, C. M., and Z. Werb. 1991. Extracellular matrix degradation. In Cell Biology of Extracellular Matrix. Second edition. E. D. Hay, editor. Plenum Press, New York. 255-304.

11. Welgus, H. G., E. G. Campbell, J. D. Cury, A. Z. Eisen, R. M. Senior S. M. Wilhelm, and G. I. Goldberg. 1990. Neutral metalloproteinases produced by human mononuclear phagocytes. Enzyme profile, regulation, and expression during cellular development. J. Clin. Invest. 86:1496-1502.

12. Ståhle-Bäckdahl, M., B. D. Sudbeck, A. Z. Eisen, H. G. Welgus, and W. C. Parks. 1992. Expression of $92 \mathrm{kDa}$ type IV collagenase by eosinophils associated with basal cell carcinoma. J. Invest. Dermatol. 99:497-503.

13. Ståhle-Bäckdahl, M., and W. C. Parks. $1993.92 \mathrm{kDa}$ gelatinase is actively expressed by eosinophils and secreted by neutrophils in invasive squamous cell carcinoma. Am. J. Pathol. 142:995-1000.

14. Hibbs, M. S., K. A. Hasty, J. M. Seyer, A. M. Kang, and C. L. Mainardi. 1985. Biochemical and immunological characterization of secreted forms of human neutrophil gelatinase. J. Biol. Chem. 260:2493-2500.

15. Senior, R. M., G. L. Griffin, C. J. Fliszar, S. D. Shapiro, G. I. Goldberg, and H. G. Welgus. 1991. Human 92-kilodalton and 72-kilodalton type IV collagenases are elastases. J. Biol. Chem. 266:7870-7875.

16. Sires, U. I., G. L. Griffin, T. Broekelmann, R. P. Mecham, G. Murphy, A. E. Chung, H. G. Welgus, and R. M. Senior. 1993. Degradation of entactin by matrix metalloproteinases. Susceptibility to matrilysin and identification of cleavage sites. J. Biol. Chem. 268:2069-2074.

17. Westgate, G. E., A. C. Weaver, and J. R. Couchman. 1985. Bullous pemphigoid antigen localization suggests an intracellular association with hemidesmosomes. J. Invest. Dermatol. 84:218-224.

18. Sonnenberg, A., J. Calafat, H. Janssen, H. Daams, L. M. H. van der Raaij-Helmer, R. Falcioni, S. J. Kennel, J. D. Aplin, J. Baker, M. Loizidou, and D. Garrod. 1991. Integrin $\alpha 6 / \beta 4$ complex is located in hemidesmosomes, suggesting a major role in epidermal cell-basement membrane adhesion. J. Cell Biol. 113:907-917.

19. Tanaka, T., D. A. D. Parry, V. Klaus-Kovtun, P. M. Steinert, and J. R. Stanley. 1991. Comparison of molecularly cloned bullous pemphigoid antigen to desmoplakin I confirms that they define a new family of cell adhesion junction plaque proteins. J. Biol. Chem. 266:12555-12559.

20. Sawamura, D., K. Li, M.-L. Chu, and J. Uitto. 1991. Human bullous pemphigoid antigen (BPAG1). Amino acid sequences deduced from cloned cDNAs predict biologically important peptide segments and protein domains. $J$. Biol. Chem. 266:17784-17790.

21. Wiche, G., B. Becker, K. Luber, G. Weitzer, M. J. Castoñon, R. Hauptmann, C. Stratowa, and M. Stewart. 1991. Cloning and sequencing of rat plectin indicates a $466-\mathrm{kD}$ polypeptide chain with a three-domain structure based on a central alpha-helical coiled coil. J. Cell Biol. 114:83-99.

22. Diaz, L. A., H. Ratrie, W. S. Saunders, S. Futamura, H. L. Squiquera, G. J. Anhalt, and G. J. Giudice. 1990. Isolation of human epidermal cDNA corresponding to the $180-\mathrm{kD}$ autoantigen recognized by bullous pemphigoid and herpes gestationus sera. Immunolocalization of this protein to the hemidesmosome. J. Clin. Invest. 86:1088-1094.

23. Giudice, G. J., D. J. Emery, and L. A. Diaz. 1992. Cloning and primary structural analysis of the bullous pemphigoid autoantigen BP180. J. Invest. Dermatol. 99:243-250.

24. Hopkinson, S. B., K. S. Riddelle, and J. C. R. Jones. 1992. Cytoplasmic domain of the $180-\mathrm{kD}$ bullous pemphigoid antigen, a hemidesmosomal component: molecular and cell biologic characterization. J. Invest. Dermatol. 99:264270.

25. Nishizawa, Y., J. Uematsu, and K. Gwaribe. 1993. HD4, a $180 \mathrm{kDa}$ bullous pemphigoid antigen, is a major transmembrane glycoprotein of the hemidesmosome. J. Biochem. (Tokyo). 113:493-501.

26. Giudice, G. J., D. J. Emery, B. D. Zelickson, G. J. Anhalt, Z. Liu, and L. A. Diaz. 1993. Bullous pemphigoid and herpes gestationis autoantibodies recognize a common non-collagenous site on the BP180 ectodomain. J. Immunol. 151:5742-5750.

27. Kiistala, U. 1968. Suction blister device for separation of viable epidermis from dermis. J. Invest. Dermatol. 50:129-137.

28. Prosser, I. W., K. R. Stenmark, M. Suthar, E. C. Crouch, R. P. Mecham, and W. C. Parks. 1989. Regional heterogeneity of elastin and collagen gene expression in intralobar arteries in response to hypoxic pulmonary hypertension as demonstrated by in situ hybridization. Am. J. Pathol. 135:1073-1088.

29. Fox, C. H., T. Kotler, T. Tierney, C. S. Wilson, and A. S. Fauci. 1989.
Detection of HIV-1 RNA in the lamina propria of patients with AIDS and gastrointestinal disease. J. Infect. Dis. 159:467-471.

30. Patterson, S., J. Gross, and A. D. B. Webster. 1989. DNA probes bind nonspecifically to eosinophils during in situ hybridization: carbol chromotrope blocks binding to eosinophils but does not inhibit hybridization to specific nucleotide sequences. J. Virol. Methods. 23:105-109.

31. Wilhelm, S. M., I. E. Collier, B. L. Marmer, A. Z. Eisen, G. A. Grant, and G. A. Goldberg. 1989. SV-40 transformed human lung fibroblasts secrete $92-\mathrm{kDa}$ type IV collagenase which is identical to that secreted by normal human macrophages. J. Biol. Chem. 264:17213-17221.

32. Sirum, K. L., and C. E. Brinckerhoff. 1989. Cloning of the genes for human stromelysin and stromelysin 2: differential expression in rheumatoid synovial fibroblasts. Biochemistry. 28:8691-8698.

33. Saarialho-Kere, U. K., E. S. Chang, H. G. Welgus, and W. C. Parks. 1992. Distinct localization of collagenase and TIMP expression in wound healing associated with ulcerative pyogenic granuloma. J. Clin. Invest. 90:1952-1957.

34. McDonnell, S., M. Navre, R. J. Coffrey, and L. M. Matrisian. 1991 Expression and localization of the matrix metalloproteinase Pump-1 (MMP-7) in human gastric and colon carcinomas. Mol. Carcinog. 4:527-533.

35. Sudbeck, B. D., J. J. Jeffrey, H. G. Welgus, R. P. Mecham, D. McCourt, and W. C. Parks. 1992. Purification and characterization of bovine collagenase and tissue inhibitor of metalloproteinases. Arch. Biochem. Biophys. 293:370376.

36. Saus, J., S. Quinones, Y. Otani, H. Nagase, E. D. Harris, and M. Kurkinen. 1988. The complete primary structure of human matrix metalloproteinase-3. J. Biol. Chem. 263:6742-6745.

37. Liptay, M. J., W. C. Parks, R. P. Mecham, J. Roby, L. R. Kaiser, J. D. Cooper, and M. D. Botney. 1993. Neointimal macrophages co-localize with extracellular matrix gene expression in human atherosclerotic pulmonary arteries. J. Clin. Invest. 91:588-594.

38. Pulford, K. A. F., E. M. Rigney, K. J. Micklem, W. P. Stross, K. C. Gatter, and D. Y. Mason. 1989. KP1: a new monoclonal antibody that detects a monocyte/macrophage associated antigen in routinely processed tissue sections. $J$. Clin. Pathol. 42:414-421.

39. Heussen, C., and E. B. Dowdle. 1980. Electrophoretic analysis of plasminogen activators in polyacrylamide gels containing sodium dodecyl sulfate and copolymerized substrates. Anal. Biochem. 102:196-202.

40. Saarialho-Kere, U. K., H. G. Welgus, and W. C. Parks. 1993. Divergent mechanisms regulate interstitial collagenase and $92 \mathrm{kDa}$ gelatinase expression in human monocytic-like cells exposed to bacterial endotoxin. J. Biol. Chem. 268:17354-17361.

41. Liu, Z., L. A. Diaz, A. L. Haas, and G. J. Giudice. 1992. cDNA cloning of a novel human ubiquitin carrier protein. An antigenic domain specifically recognized by endemic pemphigus foliaccus autoantibodies is encoded in a secondary reading frame of this human epidermal transcript. J. Biol. Chem. 267:1582915835

42. Sarret, Y., D. T. Woodley, G. I. Goldberg, A. Kroneberger, and K. C. Wynn. 1992. Constitutive synthesis of a 92-kDa keratinocyte-derived type IV collagenase is enhanced by type I collagen and decreased by type IV collagen matrices. J. Invest. Dermatol. 99:836-841.

43. Hibbs, M. S., J. R. Hoidal, and A. H. Kang. 1987. Expression of a metalloproteinase that degrades native type $\mathbf{V}$ collagen and denatured collagens by cultured human alveolar macrophages. J. Clin. Invest. 80:1644-1650.

44. Kuhns, D. B., E. DeCarlo, D. M. Hawk, and J. I. Gallin. 1992. Dynamics of the cellular and humoral components of the inflammatory response elicited in skin blisters in humans. J. Clin. Invest. 89:1734-1740.

45. Goldberg, G. I., A. Strongin, I. E. Collier, L. T. Genrich, and B. L. Marmer. 1992. Interaction of 92-kDa type IV collagenase with the tissue inhibito of metalloproteinases prevents dimerization, complex formation with interstitial collagenase, and activation of the proenzyme with stromelysin. J. Biol. Chem 267:4583-4591.

46. Farb, R. M., R. Dykes, and G. S. Lazarus. 1978. Anti-epidermal-cell-surface pemphigus antibody detaches viable epidermal cells from culture plates by activation of proteinases. Proc. Natl. Acad. Sci. USA. 75:459-463.

47. Schiltz, J. R., B. Michel, and R. Papay. 1979. Appearance of "pemphigus acantholysis factor" in human skin cultured with pemphigus antibody. J. Invest. Dermatol. 73:575-581.

48. Gammon, W. R., C. C. Merritt, D. M. Lewis, W. M. Sams, J. R. Carlo, and C. Wheeler. 1982 An in vitro model of immune complex-mediated basemen membrane zone separation caused by pemphigoid antibodies, leukocytes, and complement. J. Invest. Dermatol. 78:285-290.

49. Naito, K. S. Morioka, and H. Ogawa. 1982. The pathogenic mechanisms of blister formation in bullous pemphigoid. J. Invest. Dermatol. 79:303-306.

50. Saarialho-Kere, U. K., S. O. Kovacs, A. P. Pentland, J. Olerud, H. G. Welgus, and W. C. Parks. 1993. Cell-matrix interactions influence interstitial collagenase expression by human keratinocytes actively involved in wound healing. J. Clin. Invest. 92:2858-2866.

51. Giudice, G. J., L. Squiquera, P. M. Elias, and L. A. Diaz. 1991. Identifica- 
tion of two collagen domains within the bullous pemphigoid autoantigen BP180. J. Clin. Invest. 87:734-738.

52. Li, K., K. Tamai, E. M. L. Tan, and J. Uitto. 1993. Cloning of type XVII collagen. Complementary and genomic DNA sequences of mouse 180-kilodalton bullous pemphigoid antigen (BPAG2) predict an interrupted collagenous domain, a transmembrane segment, and unusual features in the 5'-end of the gene and 3'-untranslated sequences of the mRNA. J. Biol. Chem. 268:8825-8834.

53. Murphy, G., M. I. Cockett, R. V. Ward, and A. J. P. Docherty. 1991. Matrix metalloproteinase degradation of elastin, type IV collagen and proteoglycan. A quantitative comparison of the activities of $95 \mathrm{kDa}$ and $75 \mathrm{kDa}$ gelatinases, stromelysins-1 and -2 and punctuated metalloproteinase (PUMP). Biochem. $J$ 277:277-279.

54. Busiek, D. F., F. P. Ross, S. McDonnell, G. Murphy, L. M. Matrisian, and H. G. Welgus. 1992. The matrix metalloprotease matrilysin (PUMP) is expressed in developing human mononuclear phagocytes. J. Biol. Chem. 13:9087-9092.

55. Rodgers, W. H., K. G. Osteen, L. M. Matrisian, M. Navre, G. L. C., and F. Gorstein. 1993. Expression and localization of matrilysin, a matrix metalloproteinase, in human endometrium during the reproductive cycle. Am. J. Obstet. Gynecol. 168:253-260.
56. Saarialho-Kere, U. K., E. S. Chang, H. G. Welgus, and W. C. Parks. 1993. Expression of interstitial collagenase, $92 \mathrm{kDa}$ gelatinase, and TIMP-1 in granuloma annulare and necrobiosis lipoidica diabeticorum. J. Invest. Dermatol. 100:335-342.

57. Hayakawa, T., K. Yamashita, K. Tanzawa, E. Uchujima, and K. Iwata. 1992. Growth-promoting activity of tissue inhibitor of metalloproteinase-1 (TIMP-1) for a wide range of cells. FEBS (Fed. Eur. Biochem. Soc.) Lett. 298:2932.

58. Takigawa, M. Y. Nishida, F. Suzuki, J. Kishi, K Yamashita, and T. Hayakiana. 1990. Induction of angiogenesis in chick yolk sac membrane by polyamines and its inhibition by TIMP and TIMP 2. Biochem. Biophys. Res. Commun. 171:1264-1271.

59. Werb, Z., P. M. Tremble, O. Behrendtsen, E. Crowley, and C. H. Damsky. 1989. Signal transduction through the fibronectin receptor induces collagenase and stromelysin gene expression. J. Cell Biol. 109:877-889.

60. Gammon, R. W., C. C. Merritt, D. M. Lewis, M. W. Sams, C. E. Wheeler, and J. R. Carlo. 1982. Functional evidence for complement-activating immune complexes in the skin of patients with bullous pemphigoid. J. Invest. Dermatol. 78:52-57. 